\title{
Properties of Q-Type Calcium Channels in Neostriatal and Cortical Neurons are Correlated with $\beta$ Subunit Expression
}

\author{
Paul G. Mermelstein, ${ }^{2}$ Robert C. Foehring, ${ }^{2}$ Tatiana Tkatch, ${ }^{1}$ Wen-Jie Song, ${ }^{2}$ Gytis Baranauskas, ${ }^{1}$ and \\ D. James Surmeier ${ }^{1}$
}

1Department of Physiology/NUIN, Northwestern University Medical School, Chicago, Illinois 60611, and 2Department of Anatomy and Neurobiology, College of Medicine, University of Tennessee, Memphis, Tennessee 38163

\begin{abstract}
In brain neurons, $\mathrm{P}$ - and Q-type $\mathrm{Ca}^{2+}$ channels both appear to include a class $\mathrm{A} \alpha 1$ subunit. In spite of this similarity, these channels differ pharmacologically and biophysically, particularly in inactivation kinetics. The molecular basis for this difference is unclear. In heterologous systems, alternative splicing and ancillary $\beta$ subunits have been shown to alter biophysical properties of channels containing a class $\mathrm{A} \alpha 1$ subunit. To test the hypothesis that similar mechanisms are at work in native systems, P- and Q-type currents were characterized in acutely isolated rat neostriatal, medium spiny neurons and cortical pyramidal neurons using whole-cell voltage-clamp techniques. Cells were subsequently aspirated and subjected to single-cell RT-PCR (scRT-PCR) analysis of calcium channel $\alpha_{1}$ and $\beta\left(\beta_{1-4}\right)$ subunit expression. In both cortical and neostriatal neurons, $\mathrm{P}$ and Q-type currents were found in cells expressing class A $\alpha_{1}$ subunit mRNA. Although P-type currents in cortical and neostriatal neurons were similar, Q-type currents differed signifi-
\end{abstract}

cantly in inactivation kinetics. Notably, Q-type currents in neostriatal neurons were similar to P-type currents in inactivation rate. The variation in $\mathrm{Q}$-type channel biophysics was correlated with $\beta$ subunit expression. Neostriatal neurons expressed significantly higher levels of $\beta_{2 \mathrm{a}}$ mRNA and lower levels of $\beta_{1 \mathrm{~b}}$ mRNA than cortical neurons. These findings are consistent with the association of $\beta_{2 \mathrm{a}}$ and $\beta_{1 \mathrm{~b}}$ subunits with slow and fast inactivation, respectively. Analysis of $\alpha_{1 \mathrm{~A}}$ splice variants in the linker between domains I and II failed to provide an alternative explanation for the differences in inactivation rates. These findings are consistent with the hypothesis that the biophysical properties of $Q$-type channels are governed by $\beta$ subunit isoforms and are separable from toxin sensitivity.

Key words: striatum; cortex; cerebellum; medium spiny neurons; pyramidal neurons; single-cell RT-PCR; voltage clamp; calcium channels; $\alpha$ subunits; $\beta$ subunits; patch-clamp
Neuronal calcium channels are heteromeric transmembrane proteins consisting of $\alpha_{1}, \alpha_{2} \delta, \beta$, and $\gamma$ subunits (Tsien et al., 1995; Letts et al., 1998). By controlling $\mathrm{Ca}^{2+}$ entry, these channels regulate a wide variety of cellular functions including spike patterning, neurotransmitter release, and gene transcription (Holliday et al., 1991; Lancaster et al., 1991; Llano et al., 1991; Wheeler et al., 1994; Mintz et al., 1995; Bito et al., 1997; Hernandez-Lopez et al., 1997). The $\alpha_{1}$ subunit forms the pore of the channel and determines ion selectivity, voltage dependence, and toxin sensitivity (Snutch and Reiner, 1992). Attempts to match the properties of native $\mathrm{Ca}^{2+}$ channels with $\alpha_{1}$ subunits identified in cloning studies have generally met with success.

P- and Q-type channels are a notable exception to this rule. P-type calcium channels were initially described in cerebellar Purkinje neurons (Llinas et al., 1989, 1992; Usowicz et al., 1992). These very slowly inactivating channels are believed to possess a

\footnotetext{
Received March 30, 1999; revised June 3, 1999; accepted June 10, 1999.

This work was supported by United States Public Health Service Grants NS-34696 to D.J.S., NS-33579 to R.C.F., and NS-10028 to P.G.M. We thank Dr. Terry Snutch for providing sequences of spliced areas in the I-II linker region. We also thank Drs. Erika Piedras-Renteria, Stephen Smith, and Richard Tsien for their helpful comments.

Correspondence should be addressed to Dr. D. James Surmeier, Department of Physiology/NUIN, Northwestern University Medical School, Searle 5-474, 320 East Superior Street, Chicago, IL 60611.

Dr. Mermelstein's present address: Department of Molecular and Cellular Physiology, Beckman Center Room B101, Stanford University School of Medicine, Stanford, CA 94305-5345.

Dr. Song's present address: Division of Biophysical Engineering, Osaka University, Toyonaka, Osaka 560 Japan.

Copyright (C) 1999 Society for Neuroscience 0270-6474/99/197268-10\$05.00/0
}

class $\mathrm{A} \alpha_{1}\left(\alpha_{1 \mathrm{~A}}\right)$ subunit, because $\alpha_{1 \mathrm{~A}}$ mRNA is expressed in high abundance within the cerebellum and Purkinje neurons (Mori et al., 1991; Starr et al., 1991; Stea et al., 1994). This conjecture has been strengthened by the localization of $\alpha_{1 \mathrm{~A}}$ protein in Purkinje neurons (Westenbroek et al., 1995) and the ability of antisense $\alpha_{1 \mathrm{~A}}$ cDNA to knock down P-type currents in Purkinje neurons and cerebellar granule cells (Gillard et al., 1997; Piedras-Renteria and Tsien, 1998). However, heterologous expression of $\alpha_{1 \mathrm{~A}}$ subunits results in calcium currents that are different from P-type currents in at least two respects (Sather et al., 1993; Niidome et al., 1994). One difference is in toxin sensitivity: heterologous $\alpha_{1 \mathrm{~A}}$ channels display a reduced sensitivity to $\omega$-agatoxin-IVA (AgTx) while exhibiting a higher sensitivity to $\omega$-conotoxin-M VIIC (CTx MVIIC) (Hillyard et al., 1992; Sather et al., 1993). Another mismatch is in inactivation rate: heterologous $\alpha_{1 \mathrm{~A}}$ channels display significantly more inactivation at depolarized potentials than do P-type channels. These differences do not appear to be expression system artifacts because channels with pharmacological and biophysical properties similar to those seen in Xenopus oocytes after $\alpha_{1 \mathrm{~A}}$ cRNA injection have been found in several neuronal types (Eliot and Johnston, 1994; Wheeler et al., 1994; Diochot et al., 1995; Randall and Tsien, 1995; Foehring and Armstrong, 1996; McDonough et al., 1996; Desmadryl et al., 1997; Wang et al., 1997). This latter group of channels has been referred to as Q-type (Randall and Tsien, 1995).

There are several possible explanations for the variation in channel properties. One is that $\mathrm{P}$ - and Q-type channels are reflections of $\alpha_{1 \mathrm{~A}}$ splice variants (Mori et al., 1991; Starr et al., 
1991; Sakurai et al., 1995, 1996; Bourinet et al., 1999). Another possibility is that P- and Q-type channels have the same poreforming subunit (Pinto et al., 1998) but different $\beta$ subunits. Studies in heterologous systems have shown that the inactivation rates of $\alpha_{1 \mathrm{~A}}$ channels can be dramatically affected by $\beta$ subunits (Sather et al., 1993; Stea et al., 1994; De Waard and Campbell, 1995). However, there has been no attempt to explicitly examine either hypothesis in a native expression system. In an attempt to fill this gap, P- and Q-type currents first were characterized in acutely isolated, rat cortical pyramidal neurons and neostriatal medium spiny neurons using patch-clamp techniques. Then, the $\alpha_{1}$ and $\beta$ subunit mRNAs expressed by these neurons were characterized using single-cell RT-PCR techniques.

\section{MATERIALS AND METHODS}

Acute dissociation. Neostriatal and cortical pyramidal neurons from $\geq 4$ week-old rats were acutely dissociated using previously described protocols (Bargas et al., 1994; Lorenzon and Foehring, 1995). Rats were decapitated, and their brains were removed after being anesthetized with methoxyflurane (Mallinckrodt Veterinary, Mundelein, IL). The brains were then blocked and sliced on a DSK microslicer (Ted Pella, Redding, $\mathrm{CA}$ ) in a cold sucrose solution (in mM): 234 sucrose, $2.5 \mathrm{KCl}, 1 \mathrm{Na}_{2} \mathrm{HPO}_{4}$, 11 glucose, $4 \mathrm{MgSO}_{4}, 0.1 \mathrm{CaCl}_{2}$, and $15 \mathrm{HEPES}, \mathrm{pH} 7.35,300 \mathrm{mOsm} / 1$. Unless stated otherwise, all chemicals were obtained from Sigma (St. Louis, MO). Coronal slices $(400 \mu \mathrm{m})$ were incubated $0.5-6 \mathrm{hr}$ at room temperature in a sodium bicarbonate-buffered, Earle's balanced salt solution bubbled with $95 \% \mathrm{O}_{2}$ and $5 \% \mathrm{CO}_{2}$, and containing (in $\mathrm{mm}$ ) 1 kynurenic acid, 1 pyruvic acid, $0.1 \mathrm{~N}$-nitroarginine, and 0.005 glutathione, $\mathrm{pH} 7.4,300 \mathrm{mOsm} / 1$. Individual slices were then placed in a $\mathrm{Ca}^{2+}$-free buffer (in $\mathrm{mM}$ ): $140 \mathrm{Na}$-isethionate, $2 \mathrm{KCl}, 4 \mathrm{MgCl}_{2}, 23$ glucose, 15 $\mathrm{HEPES}$, pH 7.4, $300 \mathrm{mOsm} / 1$, and under a dissecting microscope, the neostriatum or cortex was isolated. For experiments using neostriatal tissue, dissections were limited to regions rostral to the decussation of the anterior commisure to avoid contamination from the globus pallidus. For experiments using cortical neurons, only frontal cortex areas 1 and 3 and the forelimb area of cortex $0.2-1.7 \mathrm{~mm}$ anterior to bregma were used. The isolated tissue was then placed into an oxygenated, HEPES-buffered HBSS containing $1.5 \mathrm{mg} / \mathrm{ml}$ protease (type XIV) at $35^{\circ} \mathrm{C}$ for $30 \mathrm{~min}$. The enzyme chamber also contained the kynurenic acid, pyruvic acid, $N$-nitroarginine, and glutathione supplements ( $\mathrm{pH} 7.4,300 \mathrm{mOsm} / \mathrm{l})$. After enzymatic treatment, the tissue was rinsed in the $\mathrm{Ca}^{2+}$-free buffer and triturated with a series of fire-polished Pasteur pipettes. The cell suspension was then placed in a $35 \mathrm{~mm}$ Lux Petri dish (Nunc, Naperville, IL) that was positioned on the stage of an inverted microscope. Cells were allowed to settle for several minutes before recording.

Whole-cell recordings. Whole-cell recordings were performed using standard techniques (Hamill et al., 1981; Bargas et al., 1994). Corning 7052 glass electrodes were pulled (Flaming-Brown P-97 puller; Sutter Instrument Company, Novato, CA) and fire polished (MF-83 microforge; Narishige, Hempstead, NY) just before use. The intracellular recording solution contained (in $\mathrm{mM}$ ): $190 \mathrm{~N}$-methyl-D-glucamine, 40 HEPES, 5 BAPTA, 12 phosphocreatine, $3 \mathrm{Na}_{2} \mathrm{ATP}, 0.2 \mathrm{Na}_{3} \mathrm{GTP}$, and 4 $\mathrm{MgCl}_{2}, \mathrm{pH} 7.2$ (with $\mathrm{H}_{2} \mathrm{SO}_{4}$ ), $275 \mathrm{mOsm} / 1$. The external recording solution contained (in mM): $135 \mathrm{NaCl}, 10 \mathrm{HEPES}, 1 \mathrm{MgCl}_{2}, 20 \mathrm{CsCl}_{2}, 5$ $\mathrm{BaCl}_{2}$, and 0.001 tetrodotoxin (TTX), pH 7.35, $300 \mathrm{mOsm} / 1$. ATP and GTP were obtained from Boehringer Mannheim (Indianapolis, IN) and BAPTA from Calbiochem (La Jolla, CA). Extracellular recording solutions were applied via one of a series of six glass capillaries $(\sim 150 \mu \mathrm{m}$ inner diameter) in which gravity flow was regulated by $12 \mathrm{~V}$ electronic valves (Lee Company, Essex, CT). Solution changes were performed by altering the position of the drug array using a DC drive system controlled by a microprocessor-based controller (PMC 100 or 200; NewportKlinger, Irvine, CA). A continuous flow of background solution (in mM: $140 \mathrm{NaCl}, 23$ glucose, $15 \mathrm{HEPES}, 2 \mathrm{KCl}, 2 \mathrm{MgCl}_{2}$, and $1 \mathrm{CaCl}_{2}, \mathrm{pH} 7.4$, $300 \mathrm{mOsm} / \mathrm{l}$ ) was maintained to clear applied agents.

Recordings were obtained with an Axon Instruments (Foster City, CA) 200A or Dagan 3900 patch-clamp amplifier, controlled and monitored with a PC 486 running pClamp (version 5.0 or 6.0 ) with a $125 \mathrm{kHz}$ interface (Axon Instruments). Electrode resistances were $\sim 3-6 \mathrm{M} \Omega$ in bath. After formation of a $\mathrm{G} \Omega$ seal and subsequent cell rupture, series resistance was compensated $(75-85 \%)$ and periodically monitored. Recordings were obtained from medium-sized neostriatal projection neu- rons $(4-8 \mathrm{pF})$ and medium-sized cortical pyramidal neurons $(10-15 \mathrm{pF})$. All recordings were from cells that had short proximal dendrites. Voltage control was determined by examining tail currents after strong depolarizations. Cells in which the tail current did not decay rapidly and smoothly were discarded. Recordings were performed at room temperature. The liquid junction potential $(\sim 2 \mathrm{mV})$ was not compensated. Estimates of membrane permeability as a function of voltage were made using the Goldman-Hodgkin-Katz constant current equation (Hille, 1992; Bargas et al., 1994). Nifedipine was obtained from Research Biochemicals (Natick, MA) and $\omega$-conotoxin-GVIA (CTx GVIA) from Bachem Bioscience (King of Prussia, PA). AgTx was a generous gift from Pfizer (Groton, CT). CTx MVIIC was obtained initially as a gift from Neurex (Menlo Park, CA) and later was purchased from Bachem.

Single-cell RT-PCR. Single-cell RT-PCR was performed using protocols similar to those previously described (Surmeier et al., 1996; Mermelstein and Surmeier, 1997; Yan et al., 1997; Tkatch et al., 1998). For all experiments, electrode glass was heated to $200^{\circ} \mathrm{C}$ for $\geq 4 \mathrm{hr}$ before being pulled. The extracellular solution used nominally RNase-free water (Milli-Q PF; Millipore, Bedford, MA), whereas intracellular solution contained diethylpyrocarbonate (DEPC)-treated water. Gloves were worn by the experimenter at all times during the procedure.

After seal rupture, the cell was aspirated into the electrode. The electrode solution $(\sim 5 \mu \mathrm{l})$ was then ejected into a thin-walled PCR tube (MJ Research, Watertown, MA) containing $5 \mu$ l of DEPC-treated water, $0.5 \mu \mathrm{l}$ RNAsin $(40 \mathrm{U} / \mu \mathrm{l}), 0.5 \mu \mathrm{l}$ dithiothreitol (DTT; $0.1 \mathrm{M}$ ), and $1 \mu \mathrm{l}$ oligo-dT $(0.5 \mu \mathrm{g} / \mathrm{ml})$. The tube was heated to $70^{\circ} \mathrm{C}$ for $10 \mathrm{~min}$ to linearize mRNA and then placed on ice for $\geq 1 \mathrm{~min}$. Single-strand cDNA was generated from mRNA by adding to the PCR tube, $1 \mu$ l SuperScript II reverse transcriptase $(200 \mathrm{U} / \mu \mathrm{l}), 2 \mu \mathrm{l} 10 \times$ PCR buffer $(200 \mathrm{mM}$ Tris-HCl, $500 \mathrm{~mm} \mathrm{KCl}), 2 \mu \mathrm{l} \mathrm{MgCl} 2$ (25 mM), $1 \mu \mathrm{ldNTPs}(10 \mathrm{~mm}), 0.5 \mu \mathrm{l}$ RNAsin $(40 \mathrm{U} / \mu \mathrm{l})$, and $1.5 \mu \mathrm{l} \mathrm{DTT}(0.1 \mathrm{M})$. The reaction was heated at $42^{\circ} \mathrm{C}$ for $50 \mathrm{~min}$ followed by $70^{\circ} \mathrm{C}$ for $15 \mathrm{~min}$. After reverse transcription, mRNA was eliminated by the addition of $1 \mu \mathrm{l}$ RNase $\mathrm{H}(2 \mathrm{U} / \mu \mathrm{l})$ and heating the PCR tube to $37^{\circ} \mathrm{C}$ for $20 \mathrm{~min}$. All reagents except for RNAsin (Promega, Madison, WI) were obtained from Life Technologies (Grand Island, NY).

PCR amplification was performed using a thermal cycler (P-200; MJ Research). For detection of enkephalin and substance P, $2 \mu$ l of RT template was added to a thin-walled PCR tube containing $4 \mu \mathrm{l} 10 \times \mathrm{PCR}$ buffer (100 mM Tris-HCl, $500 \mathrm{~mm} \mathrm{KCl),} 4 \mu \mathrm{l} \mathrm{MgCl}_{2}(25 \mathrm{~mm}), 0.8 \mu \mathrm{l}$ dTNPs $(25 \mathrm{~mm}), 2 \mu \mathrm{l}$ upstream primer for either enkephalin or substance $\mathrm{P}(20 \mu \mathrm{M}), 2 \mu \mathrm{l}$ downstream primer $(20 \mu \mathrm{M}), 21 \mu \mathrm{l}$ autoclaved water, and $0.5 \mu \mathrm{T} \mathrm{Taq}$ polymerase $(5000 \mathrm{U} / \mathrm{ml})$. The thermal cycling program for peptide amplification was $94^{\circ} \mathrm{C}$ for $1 \mathrm{~min}, 59^{\circ} \mathrm{C}$ for $1 \mathrm{~min}$, and $72^{\circ} \mathrm{C}$ for 1.5 min for 45 cycles. Because of the apparent low abundance of mRNA for calcium channel $\alpha_{1}$ subunits, two-round PCR was necessary. For the first round, $4 \mu \mathrm{l}$ of template was added to a thin-walled PCR tube containing $3.6 \mu \mathrm{l} 10 \times$ PCR buffer (100 mM Tris-HCl, $500 \mathrm{~mm} \mathrm{KCl}), 3.6 \mu \mathrm{MgCl}_{2}$ $(25 \mathrm{~mm}), 0.8 \mu \mathrm{l}$ dTNPs $(25 \mathrm{mM}), 1 \mu \mathrm{l}$ upstream primer for $\alpha_{1 \mathrm{~A}}(20 \mu \mathrm{M})$, $1 \mu$ l downstream primer $(20 \mu \mathrm{M}), 23 \mu \mathrm{l}$ autoclaved water, and $0.5 \mu \mathrm{l} \mathrm{Taq}$ polymerase $(5000 \mathrm{U} / \mathrm{ml})$. The thermal cycling program for first round PCR was $94^{\circ} \mathrm{C}$ for $1 \mathrm{~min}, 59^{\circ} \mathrm{C}$ for $1 \mathrm{~min}$, and $72^{\circ} \mathrm{C}$ for $1.5 \mathrm{~min}$ for 15 cycles. For second round PCR, $2 \mu$ l of the first round PCR solution was added to another thin-walled PCR tube containing $3.8 \mu \mathrm{l} 10 \times \mathrm{PCR}$ buffer (100 mM Tris-HCl, $500 \mathrm{~mm} \mathrm{KCl),} 3.8 \mu \mathrm{lgCl}_{2}(25 \mathrm{~mm}), 0.8 \mu \mathrm{l}$ dTNPs $(25 \mathrm{~mm}), 2 \mu \mathrm{l}$ upstream primer for $\alpha_{1 \mathrm{~A}}(20 \mu \mathrm{M}), 2 \mu \mathrm{l}$ downstream primer $(20 \mu \mathrm{M}), 25 \mu \mathrm{l}$ autoclaved water, and $0.5 \mu \mathrm{l} \mathrm{Taq}$ polymerase $(5000$ $\mathrm{U} / \mathrm{ml}$ ). The thermal cycling program for peptide cDNA amplification was $94^{\circ} \mathrm{C}$ for $1 \mathrm{~min}, 59$ or $61^{\circ} \mathrm{C}$ for $1 \mathrm{~min}$, and $72^{\circ} \mathrm{C}$ for $1.5 \mathrm{~min}$ for 40 cycles. For amplification of calcium channel $\beta$ subunits, $4 \mu \mathrm{l}$ of RT template was added to a PCR tube containing $3.6 \mu \mathrm{l} 10 \times$ PCR buffer $(100 \mathrm{~mm}$ Tris-HCl, $500 \mathrm{~mm} \mathrm{KCl}), 3.6 \mu \mathrm{MgCl}_{2}(25 \mathrm{~mm}), 0.8 \mu \mathrm{l}$ dTNP $(25 \mathrm{~mm})$, $2 \mu \mathrm{l}$ upstream primer for either $\beta_{1 \mathrm{~b}}, \beta_{2 \mathrm{a}}, \beta_{3}$, or $\beta_{4}(20 \mu \mathrm{M}), 2 \mu \mathrm{l}$ downstream primer $(20 \mu \mathrm{M}), 20.5 \mu \mathrm{l}$ autoclaved water, and $0.5 \mu \mathrm{l} \mathrm{Taq}$ polymerase $(5000 \mathrm{U} / \mathrm{ml})$. The thermal cycling program for $\beta$ subunit cDNA amplification was $94^{\circ} \mathrm{C}$ for $1 \mathrm{~min}, 59^{\circ} \mathrm{C}$ for $1 \mathrm{~min}$, and $72^{\circ} \mathrm{C}$ for 1.5 min for 40 cycles. Detection thresholds for each transcript were estimated by serial dilutions of the total cellular cDNA; $10,5,2.5,1.25,0.613$, and $0.32 \mu \mathrm{l}$ of total cDNA were used as a template. PCR products were separated by electrophoresis in $1.5 \%$ agarose gels and visualized by staining with ethidium bromide. Gels were digitally imaged using a Kodak (Eastman Kodak, Rochester, NY) EDAS 120 system; gel images were processed using Kodak Image Analysis software to determine whether amplicons at the expected size were present at levels above background.

To verify working solutions were DNA-free, water was used as a 
RT-PCR template. Consistently, this control produced DNA-free products. Typical amplicons from single neostriatal neurons were sequenced with a dye termination procedure and found to match published sequences.

The PCR primers were developed from calcium channel and peptide GenBank sequences using OLIGO software (National Biosciences, Plymouth, MN). Primers were synthesized by Life Technologies. The primers for enkephalin and substance P cDNA have been published previously (Surmeier et al., 1996). Primers for the calcium channel $\alpha_{1 \mathrm{~A}}$ subunit cDNA (GenBank accession number M6437; Starr et al., 1991) were 5'-ATG GGA ACT GAT GGC TAC TCA GAC-3' (nucleotides 60646087) and 5'-TCC TCA GGT GGT ACC CGC TCT A-3' (nucleotides 6275-6296), yielding a predicted PCR product of $233 \mathrm{bp}$. The primers for $\beta_{1 \mathrm{~b}}$ cDNA (GenBank accession number X61394) (Pragnell et al., 1991) were 5'-AGC ATG CCA GTG TGC ACG AGT AC-3' (nucleotides 1445-1467) and 5'-AGC CCT CCA GCT CAT TCT TAT TGC-3' (nucleotides 1808-1831), yielding a predicted PCR product of $387 \mathrm{bp}$. The primers for $\beta_{2 a}$ cDNA (GenBank accession number M80545) (Perez-Reyes et al., 1992) were 5'-ATA ACC ACA GAG AGG AGA GCC ACA-3' (nucleotides 1970-1993) and 5'-TAT ACA TCC CTG TTC CAC TCG CCA-3' (nucleotides 2154-2177), yielding a predicted PCR product of $208 \mathrm{bp}$. The primers for $\beta_{3}$ cDNA (GenBank accession number M88751) (Castellano et al., 1993a) were 5'-TCC CTG GAC TTC AGA ACC AGC AG-3' (nucleotides 1220-1242) and 5'-TTG TGG TCA TGC TCC GAG TCC TG-3' (nucleotides 1477-1499), yielding a predicted PCR product of $280 \mathrm{bp}$. The primers for $\beta_{4}$ cDNA (GenBank accession number L02315) (Castellano et al., 1993b) were 5'-TGA GGC ATA GCA ACC ACT CTA CAG-3' (nucleotides 1512-1535) and 5'ATG TCG GGA GTC ATG GCT GCA TC-3' (nucleotides 1730-1752), yielding a predicted PCR product of $241 \mathrm{bp}$.

To examine splice variants in the linker region between domains I and II in the $\alpha_{1 \mathrm{~A}}$ transcript, nested primers were designed. The outer primers were 5'-CGA TGC CTC AGG GAA CAC TTG GAA-3' (nucleotides 990-1113) and 5'-AGA CCC CAC AGA CGC GAT GTC AG-3' (nucleotides 1337-1359), yielding a predicted PCR product of $370 \mathrm{bp}$. The inner primers were 5' -GAG GCA CCC TTT TGA-3' (nucleotides 12451259) and 5'-GTC CGT CTT GCT TTT C-3' (nucleotides 1287-1302), yielding a predicted PCR product of $58 \mathrm{bp}$. PCR was as described above except as follows. The thermal cycling program for the first round was $94^{\circ} \mathrm{C}$ for $1 \mathrm{~min}, 59^{\circ} \mathrm{C}$ for $1 \mathrm{~min}$, and $72^{\circ} \mathrm{C}$ for $1.5 \mathrm{~min}$ for 30 cycles. $\alpha_{1 \mathrm{~A}}$ inner primers were used in second-step PCR (20 cycles, annealing temperature $54^{\circ} \mathrm{C}$ ). Afterward, PCR products were separated by electrophoresis in $15 \%$ polyacrylamide gels and visualized using ethidium bromide. Negative controls to verify all solutions were RNA/DNA-free and followed similar protocols, except cellular contents were substituted with autoclaved water. The $\alpha_{1 \mathrm{~A}}$ amplicons were sequenced with a dye termination procedure by the Northwestern University Biotechnology Laboratory.

Statistics. When appropriate, between subjects $t$ tests (large samples) or Kruskal-Wallis ANOVA (small samples) were used for determination of statistical significance. Tests were run using SYSTAT (SPSS, Chicago, IL). Probabilities $\leq 0.05$ were determined a priori as significant.

\section{RESULTS}

\section{Cortical pyramidal and neostriatal medium spiny neurons express $\alpha_{1 \mathrm{~A}}$ mRNA}

Single-cell RT-PCR profiling of neostriatal medium spiny neurons dissociated from dorsal neostriatum (Fig. 1A) consistently revealed the presence of $\alpha_{1 \mathrm{~A}}$ mRNA. To insure that all major subpopulations of medium spiny neuron were sampled in these experiments, neurons were divided into three major classes on the basis of substance $\mathrm{P}$ (SP) and enkephalin (ENK) expression (Gerfen, 1992; Surmeier et al., 1996). As shown in Figure 1B, neurons in each major class of medium spiny neuron were found to express detectable levels of $\alpha_{1 \mathrm{~A}}$ mRNA. More than $90 \%$ of all medium spiny neurons profiled had detectable levels of $\alpha_{1 \mathrm{~A}}$ mRNA ( $n=36)$, suggesting that it was ubiquitously expressed. Similarly, cortical pyramidal neurons dissociated from sensorimotor cortex (Fig. 1A) consistently had detectable levels of $\alpha_{1 \mathrm{~A}}$ mRNA $(94 \%, n=18)$.
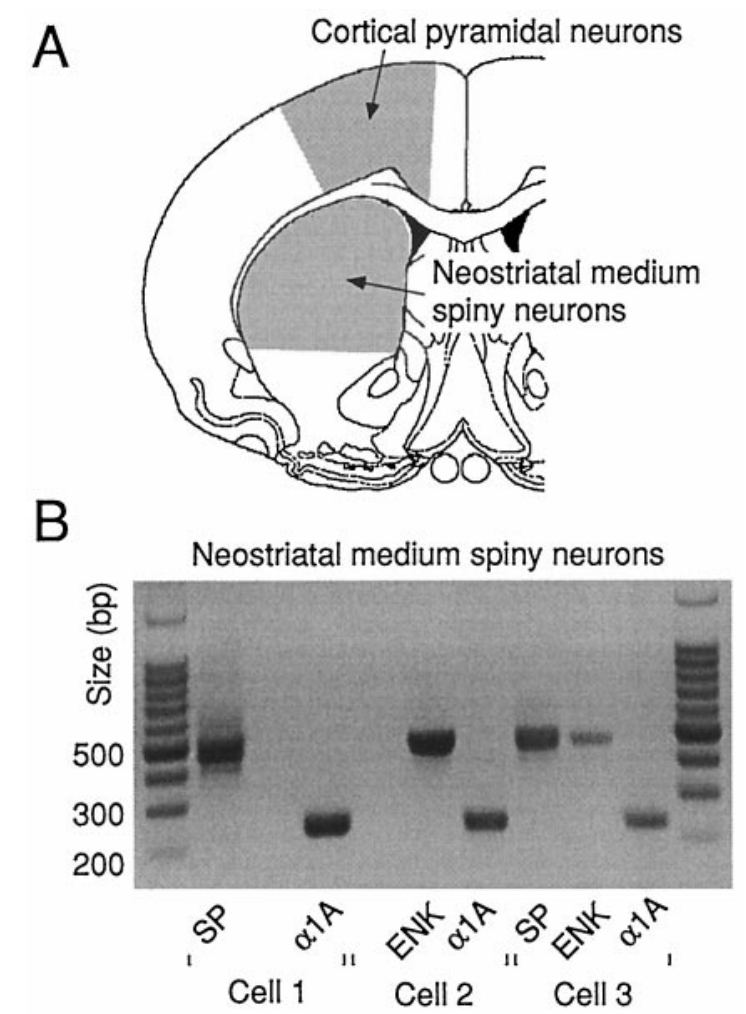

Figure 1. $\alpha_{1 \mathrm{~A}}$ mRNA is expressed in cortical pyramidal and neostriatal medium-spiny neurons. $A$, The region of the dorsal neostriatum and adjacent sensorimotor cortex in which neurons were isolated. $B$, All three major classes of neostriatal neurons express $\alpha_{1 \mathrm{~A}}$. Single-cell RT-PCR products demonstrate that neurons, which express substance P (SP) and/or enkephalin (ENK), also express $\alpha_{1 \mathrm{~A}}$. In 36 neostriatal neurons, $>90 \%$ expressed detectable levels of $\alpha_{1 \mathrm{~A}}$. Similar results were found in cortical pyramidal neurons in which $\alpha_{1 \mathrm{~A}}$ was observed in $94 \%$ of the neurons $(n=18)$.

\section{P-type currents in cortical and neostriatal neurons are slowly inactivating}

P-type currents were isolated by the bath application of 20-25 nM AgTx. This concentration of AgTx is several times the $\mathrm{IC}_{50}$ of P-type channels (2-10 nM) (Mintz et al., 1992a) but well below that of Q-type channels ( $\sim 150 \mathrm{~nm})$ (Sather et al., 1993). Within minutes, this concentration of AgTx reduced evoked currents in approximately half of all neostriatal medium spiny neurons $(n=$ 36) (Fig. $2 A)$ and in all cortical pyramidal cells $(n>25)$ (Fig. $2 C)$. P-type currents were isolated by subtracting the currents evoked before toxin application from those after 3-5 min of toxin exposure (Fig. $2 A, C$ ). Semilogarithmic plots of absolute current amplitudes were constructed and the decaying phase of the trace fit with an exponential function (Fig. $2 B, D$ ). These experiments consistently revealed that the P-type currents were very slowly inactivating, having inactivation time constants $>1 \mathrm{sec}$. A box plot summary of these fits is inset in Figure $2 D$. There were no discernible differences in the inactivation rates of cortical and neostriatal P-type currents: both were very similar in inactivation kinetics to P-type currents seen in cerebellar Purkinje neurons (Mintz et al., 1992b; Usowicz et al., 1992).

\section{Q-type currents in cortical and neostriatal neurons differed in inactivation kinetics}

Two strategies were used to isolate Q-type currents. First, L-, N-, and P-type currents were blocked with a combination of nifedi- 

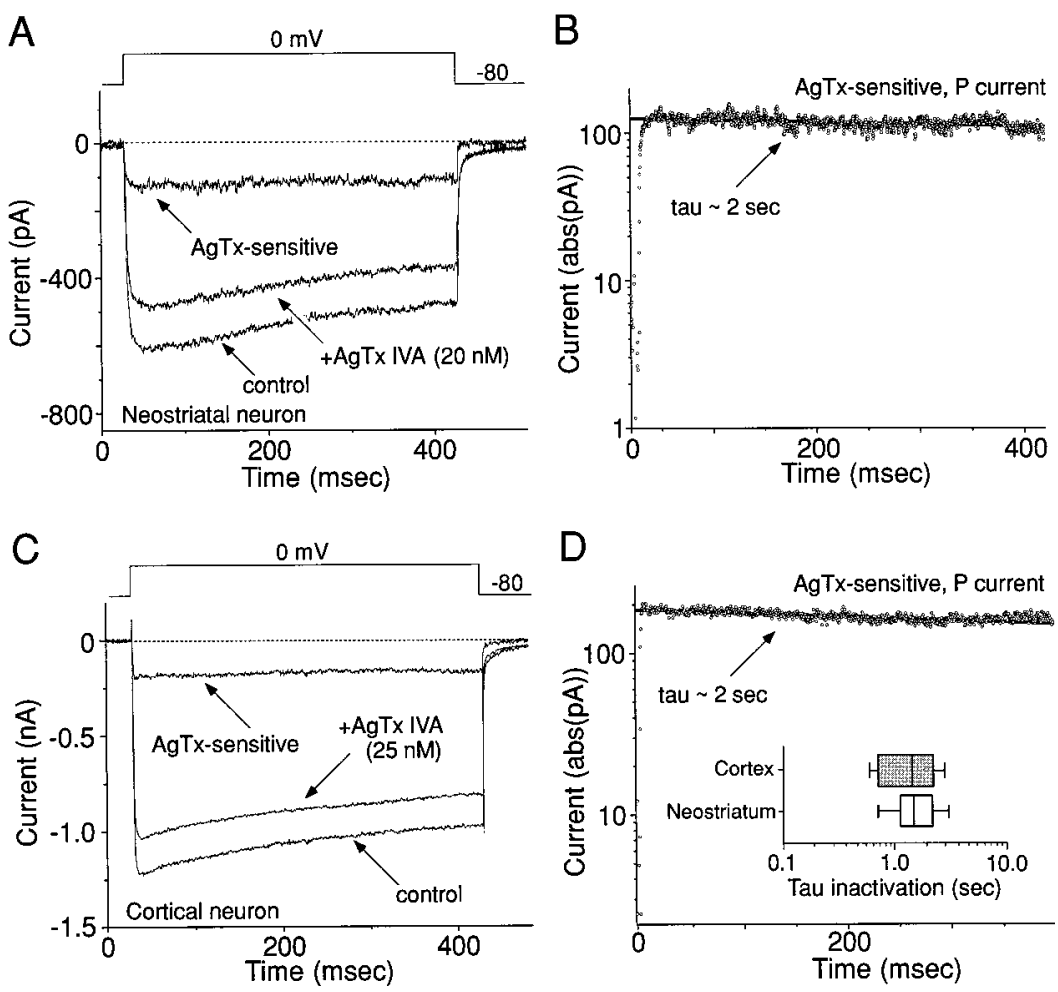

Figure 2. P-type calcium currents slowly inactivate in both cortical and neostriatal neurons. $A$, Patch-clamp recording from a neostriatal neuron in which application of $20 \mathrm{~mm}$ AgTx produced a significant block of the whole-cell current. The P-type current is isolated by subtracting the residual current after toxin administration from the control current. $B$, An exponential fit of the decay of the P-type current (expressed as absolute current vs time) demonstrates P-type currents in neostriatal neurons inactivate slowly (i.e., $\tau \sim 2$ sec). $C$, Isolation of the P-type current in a cortical neuron. $D$, As in neostriatal neurons, P-type calcium currents in cortical neurons inactivate slowly. Inset, Statistical summary of the inactivation of P-type currents in neostriatal $(n=11)$ and cortical $(n=12)$ neurons. pine (5 $\mu \mathrm{M})$, CTx GVIA (2 $\mu \mathrm{M})$, and AgTx (100 nM). Previous work had shown that these concentrations of nifedipine and CTx GVIA rapidly block L- and N-type channels in these cell types (Bargas et al., 1994; Lorenzon and Foehring, 1995). At 100 nM, AgTx rapidly blocks P-type channels while leaving a significant fraction of Q-type channels unblocked (Randall and Tsien, 1995). Q-type currents were subsequently blocked by either the application of CTx MVIIC or higher concentrations of AgTx (Randall and Tsien, 1995). As shown in Figure 3, $A$ and $B$, CTx MV IIC (1 $\mu \mathrm{M})$ produced a slow, partial block of the residual current. The kinetics of the block in neostriatal medium spiny neurons (Fig. $3 A$, inset) were similar to those previously described for Q-type currents (Sather et al., 1993; Stea et al., 1994; Randall and Tsien, 1995; McDonough et al., 1996). The blocking kinetics in cortical pyramidal neurons were indistinguishable from those of neostriatal medium spiny neurons $(n=8 ; p>0.05$; Fig. $3 A$, inset $)$.

The AgTx $(1 \mu \mathrm{M})$ block of the residual currents in neostriatal medium spiny neurons was faster than that of CTx MVIIC, but well within the range reported for the block of Q-type currents by AgTx at this concentration (Fig. 3C, inset) (Randall and Tsien, 1995). Again, the kinetics of the block in cortical pyramidal neurons was indistinguishable from neostriatal medium spiny neurons ( $n=13 ; p>0.05$; Fig. $3 C$, inset), suggesting that Q-type channels in these two cell types were pharmacologically similar. To verify that Q-type channels were effectively blocked by the higher concentration of AgTx, CTx MVIIC was applied after the block by AgTx had stabilized. In both cortical $(n=5)$ and neostriatal neurons $(n=4)$, CTx MVIIC had little or no additional effect after the response to AgTx had stabilized (Fig. 3C,D) (Eliot and Johnston, 1994; Randall and Tsien, 1995; cf., McDonough et al., 1996).

Although the Q-type channels in cortical and neostriatal neurons were pharmacologically indistinguishable, their rates of inactivation were different. Q-type channels in cortical pyramidal neurons exhibited a prominent, rapidly inactivating phase (Fig. $4 A, B)$, much like what has been described previously in heterologous and native expression systems (Sather et al., 1993; Z hang et al., 1993; Randall and Tsien, 1995). In contrast, Q-type channels in neostriatal medium spiny neurons typically displayed little or no inactivation during a $400 \mathrm{msec}$ step to $0 \mathrm{mV}$ (Fig. $4 C, D$ ). In this regard, neostriatal Q-type channels were similar to P-type channels. In a subset of neostriatal medium spiny neurons, Q-type currents exhibited a modest rapidly inactivating component, but the percent inactivation during a $400 \mathrm{msec}$ test step was significantly smaller than that seen in cortical pyramidal neurons (Fig. 4E,F).

\section{P- and Q-type currents differ in activation voltage dependence}

To determine whether currents could be distinguished on the basis of activation voltage dependence, P- and Q-type currents were isolated, and voltage ramps were applied. As we have previously shown, ramps of the appropriate speed can rapidly give an accurate picture of the current-voltage relationship of $\mathrm{Ca}^{2+}$ conductances (Bargas et al., 1994). This relationship can then be used in conjunction with the Goldman-Hodgkin-Katz constant current equation to estimate changes in permeability as a function of voltage. These estimates can readily be fit with a Boltzmann equation that provides a short-hand description of the gating process. Representative ramp currents for a neostriatal neuron before and after isolation by subtraction are shown in Figure $5 A, B$. Conversion of the ramp currents between -80 and $+20 \mathrm{mV}$ to permeability estimates are shown in Figure $5 C$ along with Boltzmann fits. In this neuron, the Q-type current activated at more hyperpolarized potentials $\left(V_{\mathrm{h}}=-15.2 \mathrm{vs}-7.2 \mathrm{mV}\right)$ and exhibited a smaller slope factor $\left(V_{\mathrm{c}}=4 \mathrm{vs} 6.3 \mathrm{mV}\right)$ than the P-type current. A statistical summary from a sample of 13 neurons is shown in Figure 5D. The median half-activation voltage of 
A

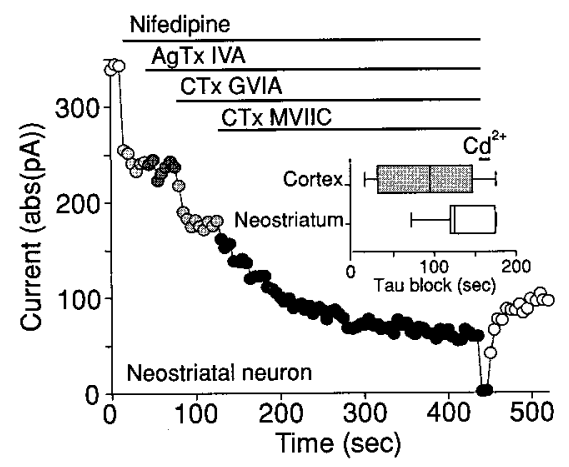

C

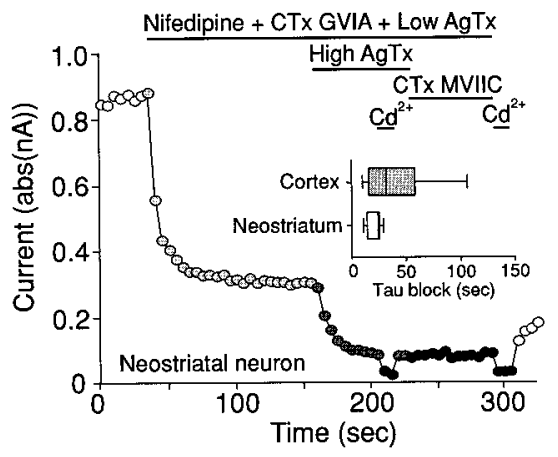

B

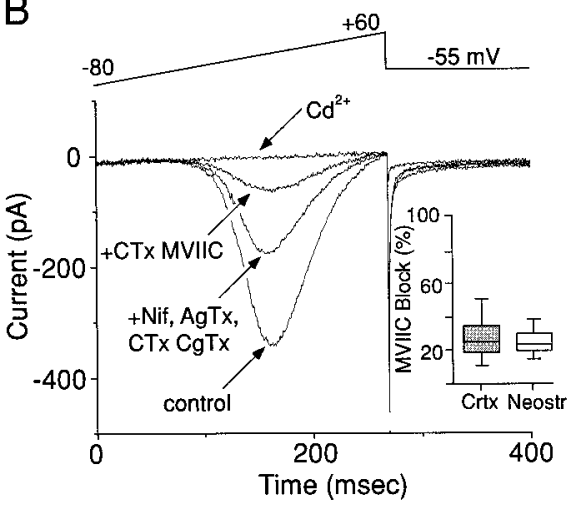

D

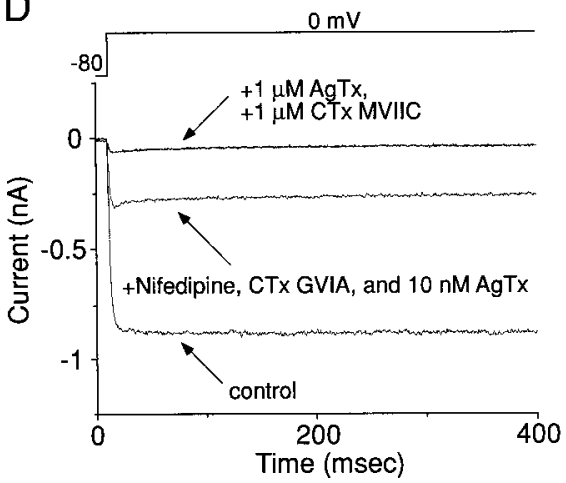

Figure 3. Isolation of the Q-type current with either $1 \mu \mathrm{M}$ CTx MVIIC or $1 \mu \mathrm{M}$ AgTx. A, Plot of peak current versus time in a neostriatal neuron. A blocked by 5 proportion of the whole-cell current was $1 \mu \mathrm{M}$ CTx MVIIC. These toxins specifically block L-, N-, and Q-type calcium currents, respectively. In this neuron, $100 \mathrm{~nm} \mathrm{AgTx}$ had no effect on the whole-cell current, indicating a lack of P-type calcium channels. Inset, The onset of CTx MVIIC block was consistent to that previously reported for Q-type calcium channels. $B$, Several of the individual traces that were used to generate the time course shown in $A$. Inset, In both neostriatal and cortical neurons, CTx MVIIC blocked $\sim 25 \%$ of the wholecell current. $C$, In a separate neostriatal neuron, after block of L-, N-, and P-type currents, Q-type channels were blocked by $1 \mu \mathrm{M}$ AgTx. This occluded the block of $1 \mu \mathrm{M}$ CTx MVIIC, indicating these toxins block the same population of channels. Inset, Onset of $1 \mu \mathrm{M}$ AgTx block. $D$, Individual traces from the time course in $C$.
P-type currents was $\sim 6 \mathrm{mV}$ more positive than Q-type currents (Fig. 5D). This difference was statistically significant $(p<0.005)$. The slope factor of the fits to P-type currents was also significantly larger than that of Q-type currents $(p<0.005)$. Similar experiments were carried out in cortical neurons (data not shown). Interestingly, on average Q-type currents activated at significantly more negative potentials $\left[V_{\mathrm{h}}=-16.8 \pm 2.6 \mathrm{mV}\right.$ (mean $\pm \mathrm{SEM}) ; n=8]$ than their neostriatal counterparts $\left(V_{\mathrm{h}}=\right.$ $-8.6 \pm 1.6 \mathrm{mV} ; n=13$; Fig. $5 D)(p<0.05)$. It is unlikely that this difference was caused by inactivation of Q-type cortical currents during the voltage ramps because previous work has shown that ramp and step protocols yield very similar data (Lorenzon and Foehring, 1995).

\section{Neostriatal and cortical neurons differentially express $\boldsymbol{\beta}$ subunit mRNA}

In heterologous systems, the inactivation kinetics of $\alpha_{1 \mathrm{~A}}$-type channels can be influenced by alternative splicing of the $\alpha_{1 \mathrm{~A}}$ subunit (Bourinet et al., 1999) or by ancillary $\beta$ subunits (Stea et al., 1994; De Waard et al., 1996). To determine whether alternative splicing of the $\alpha_{1 \mathrm{~A}}$ subunit could account for the slow inactivation rate observed in neostriatal medium spiny neurons, scRT-PCR experiments targeting the linker region between domains I and II were performed. Three splice variants of this region at the beginning of exon 3 have been described, and two of them have been functionally characterized in Xenopus oocytes (Bourinet et al., 1999). A nested priming strategy was used to isolate a 58 base pair amplicon spanning the splice site. Sequencing of the amplicon derived from a single neostriatal medium spiny neuron is shown in Figure $6 A$. The sequence corresponds to the " $a$ " splice variant. Similar results were obtained in five other neurons. Examination of cortical pyramidal neurons also only revealed the presence of the "a" splice variant $(n=4$; data not shown). When expressed in heterologous systems, this splice variant gives rise to a rapidly inactivating, Q-type current (Bourinet et al., 1999).

An alternative explanation for the slowly inactivating Q-type currents in neostriatal neurons revolves around $\beta$ subunits. In Xenopus oocytes, coexpression of $\beta_{2}$ and $\alpha_{1 \mathrm{~A}}$ subunits yield slowly inactivating currents, much like P-type currents (Stea et al., 1994; De Waard et al., 1996). Coexpression of $\beta_{4}$ or $\beta_{1 \mathrm{~b}}$ subunits with those of $\alpha_{1 \mathrm{~A}}$ subunits yields more rapidly inactivating currents. In addition, $\beta_{4}$ subunits shift the activation voltage dependence of $\alpha_{1 \mathrm{~A}}$ channels toward more negative membrane potentials. To determine whether the $\beta$ subunit expression in cortical and neostriatal neurons was consistent with this pattern, single-cell RTPCR experiments were performed in which the coordinated expression of $\beta_{1 \mathrm{~b}}, \beta_{2 \mathrm{a}}, \beta_{3}$, and $\beta_{4}$ mRNAs were examined.

As a test of primer specificity and amplification efficiency, RT-PCR experiments were performed initially with whole brain cDNA and cDNA derived just from the cerebral cortex or neostriatum. In agreement with in situ hybridization studies (Tanaka et al., 1995), these experiments revealed that all four $\beta$ subunit mRNAs were expressed at detectable levels in both neostriatum (Fig. 6B) and cerebral cortex (data not shown). Optimization of the PCR conditions led to the production of single amplicons for each primer set. Sequencing of the amplicons yielded the predicted products (Perez-Reyes et al., 1992; Castellano et al., 1993a,b; Pragnell et al., 1994).

Although all four mRNAs were detected in pooled cDNA, at the single-cell level differences in the expression of $\beta$ subunit isoform mRNAs were found when using one-quarter of the total cellular cDNA in the detection reaction. In neostriatal medium spiny neurons, $\beta_{2 \mathrm{a}}$ mRNA was the most consistently detected. $\beta_{4}$ mRNA was also relatively common, whereas $\beta_{1 \mathrm{~b}}$ mRNA was less 

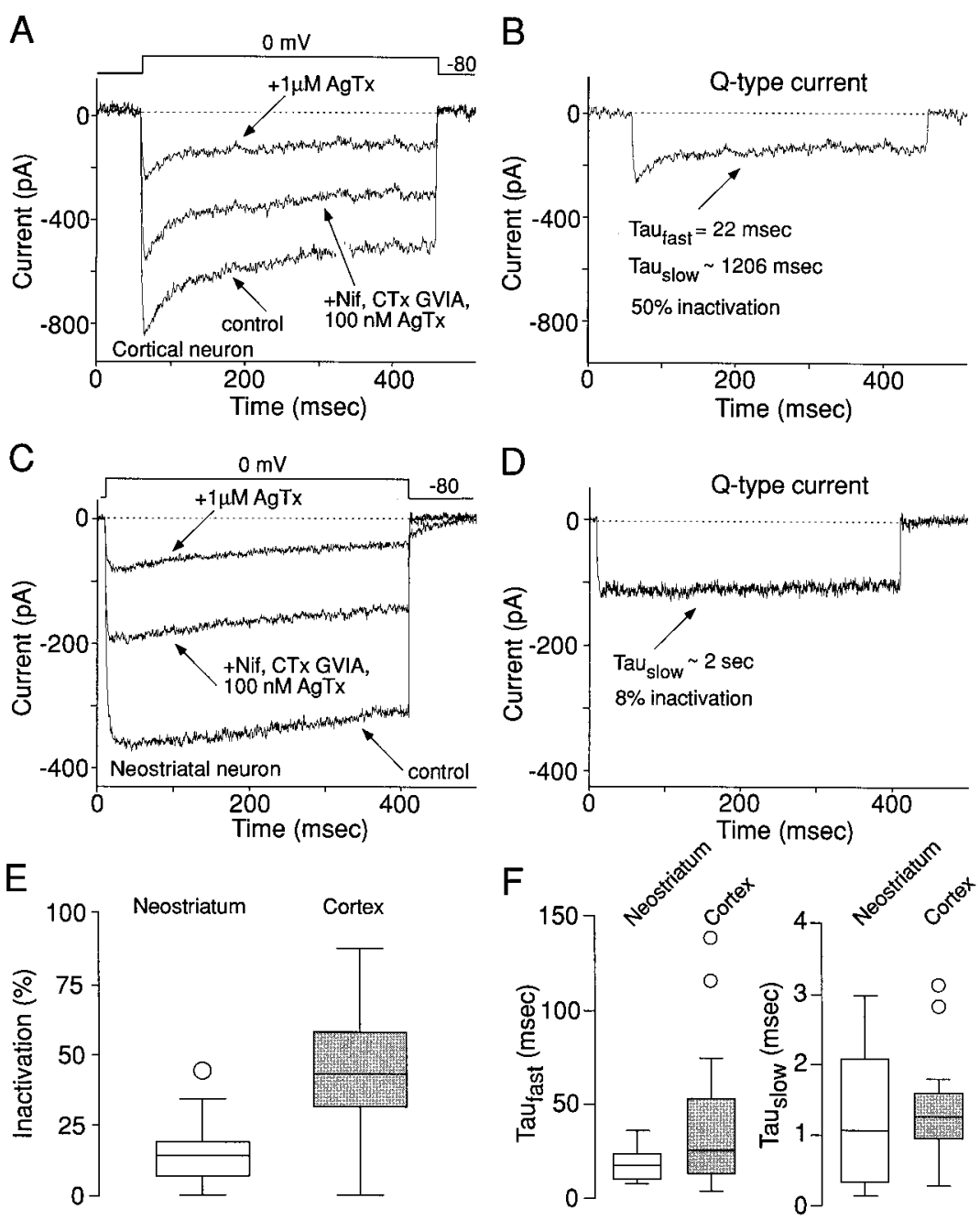

Figure 4. Q-type currents in cortical and neostriatal neurons differ in inactivation rates. $A$, Block of the Q-type current in a cortical neuron defined as the current sensitive to $1 \mu \mathrm{M} \operatorname{AgTx}$, but not $100 \mathrm{~nm} \operatorname{AgTx}$. B. Isolation of the Q-type current by subtraction. The Q-type current in this neuron exhibited a prominent, rapidly inactivating phase. $C$, Block of the Q-type current in a neostriatal neuron. $D$, Isolation of the Q-type current revealed little inactivation during a $400 \mathrm{msec}$ step to $0 \mathrm{mV}$. E, Statistical summary of the percent inactivation of Q-type currents during a $400 \mathrm{msec}$ step to $0 \mathrm{mV}$ in cortical $(n=34)$ and neostriatal $(n=20)$ neurons. The percent of current inactivation was significantly different ( $p<0.01 ; t$ test $). F$, In those cases in which a fast, as well as a slow time constant for inactivation could be fit for neostriatal Q-type currents (9 of 20), the kinetics were similar to those observed in cortical neurons $(n=20)$. frequently detected, and $\beta_{3}$ was never seen. A photograph of a gel in which the PCR amplicons derived from a single medium spiny neuron have been separated by electrophoresis is shown in Figure $6 C$. Amplicons for $\beta_{2}$ and $\beta_{4}$ mRNA are evident. A summary of these experiments is shown in Figure $6 C$ (right panel). In cortical pyramidal neurons, $\beta_{4}$ mRNA was the most commonly detected. However, both $\beta_{2 \mathrm{a}}$ and $\beta_{1 \mathrm{~b}}$ mRNA were seen in a substantial subset of neurons. A representative gel from a single cortical pyramidal neuron is shown in Figure $6 D$. A summary of the profiling experiments in pyramidal neurons is shown in the right panel.

The variation in detection probabilities for $\beta$ subunit mRNA we observed in single cells could be attributed to either low template abundance or the existence of neuronal subpopulations with distinctive expression patterns (Surmeier et al., 1996). Our working hypothesis was the former, that detection probability for a particular mRNA was directly correlated with mRNA abundance. To test this hypothesis, single-cell serial dilution experiments were performed (Song et al., 1998; Tkatch et al., 1998). The total cellular cDNA derived from individual neurons was serially diluted (by $2 \times$ ), and the greatest dilution producing a detectable amplicon was determined. As shown in Figure $6 E$, the detection thresholds in neostriatal and cortical neurons were unimodal and quasi-normally distributed, arguing that each consisted of a phenotypically homogeneous population. In agreement with the detection experiments, $\beta_{4}$ mRNA appeared to be of similar abun- dance in neostriatal and cortical neurons, with detection threshold modes of $\sim 1 / 8$ the total cellular cDNA $(p>0.05)$ (data not shown). On the other hand, the abundance of $\beta_{1 \mathrm{~b}}$ and $\beta_{2 \mathrm{a}}$ mRNAs were significantly different in cortical and neostriatal neurons. From a quantitative standpoint, $\beta_{2 \mathrm{a}}$ mRNA was relatively abundant in neostriatal medium spiny neurons, with a modal detection threshold of $\sim 1 / 8$ of the total cellular cDNA. In cortical pyramidal neurons, the detection threshold for $\beta_{2 \mathrm{a}}$ mRNA was roughly twice that of neostriatal neurons $(\sim 1 / 4)(p<$ $0.05)$, suggesting that $\beta_{2 \mathrm{a}}$ mRNA abundance was roughly half that found in neostriatal neurons. The differences in the abundance of $\beta_{1 \mathrm{~b}}$ mRNA appeared to be even more profound between cortical and neostriatal neurons $(p<0.05)$. $\beta_{1 \mathrm{~b}}$ mRNA was rarely detected in neostriatal neurons, regardless of how much cellular cDNA was used (up to $1 / 2$ the total cellular cDNA). In contrast, $\beta_{1 \mathrm{~b}}$ mRNA was readily detected in the majority of cortical pyramidal neurons, although the modal detection threshold was $1 / 2$ the cellular cDNA.

\section{DISCUSSION}

Neostriatal and cortical neurons express Q-type

Our results show that neostriatal medium spiny and cortical pyramidal neurons coexpress $\mathrm{P}$ - and Q-type $\mathrm{Ca}^{2+}$ channels. In agreement with previous work arguing that both channel types 

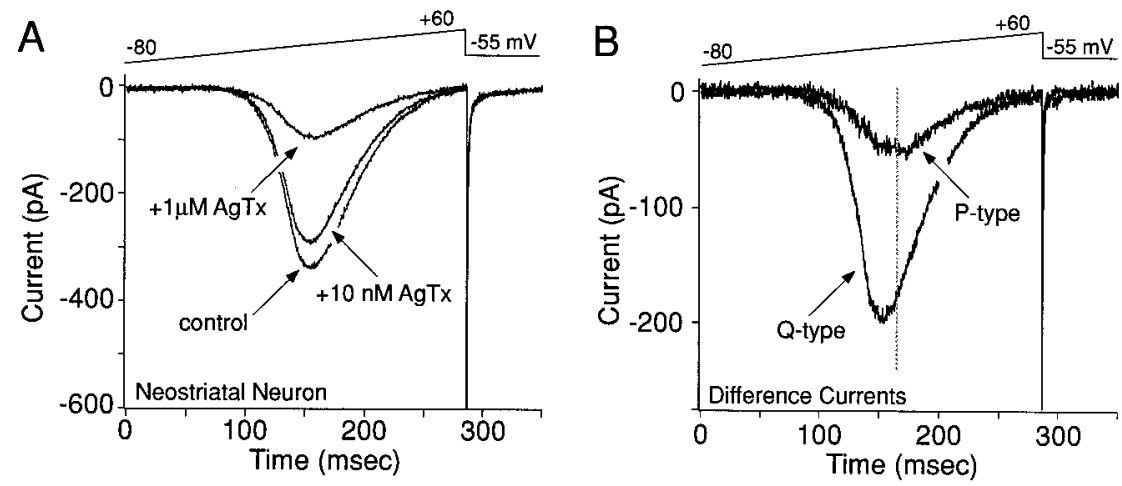

Figure 5. Neostriatal P- and Q-type calcium currents differ in voltage dependence. $A$, Block of P- and Q-type currents in a neostriatal neuron with $10 \mathrm{~nm}$ and $1 \mu \mathrm{M}$ AgTx. $B$, Isolation of P- and Q-type currents with trace subtraction. $C$, To determine permeability as a function of voltage, the currents in $B$ were divided by an estimation of the driving force using the GoldmanHodgkin-Katz constant current equation. The resulting traces were then fit with a Boltzmann equation to generate estimates of half-activation $\left(V_{\mathrm{h}}\right)$ and slope factor $\left(V_{\mathrm{c}}\right) . D$, For neostriatal neurons, Q-type currents $(n=13)$ activated at more hyperpolarized potentials and exhibited smaller slope factors than P-type currents $(n=16)(p<0.005$; Kruskal-Wallis $)$.

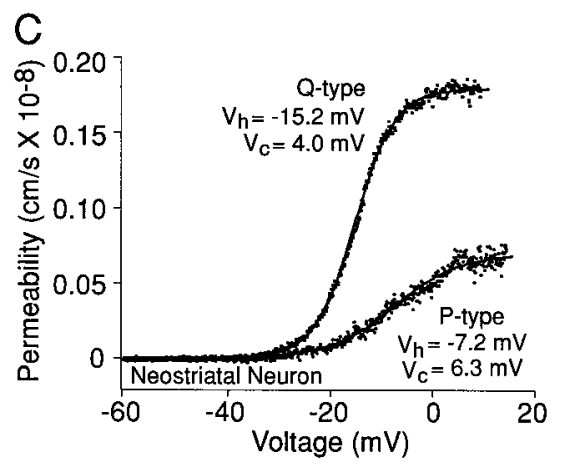

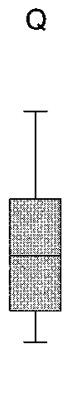

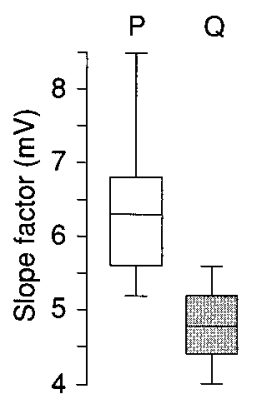

possess $\alpha_{1 \mathrm{~A}}$ subunits (Stea et al., 1994; Moreno et al., 1997; Piedras-Renteria and Tsien, 1998; Pinto et al., 1998), $\alpha_{1 \mathrm{~A}}$ mRNA was found in essentially every neuron subjected to RT-PCR analysis. Furthermore, the coexpression of P- and Q-type channels in individual cells argues that the differences between them cannot simply be ascribed to cell-type specific differential posttranscriptional or post-translational processing of a common $\alpha_{1 \mathrm{~A}}$ transcript (Randall and Tsien, 1995).

The properties of the P-type currents isolated by exposure to low nanomolar concentrations of $\omega$-AgTx IVA were similar to those described in Purkinje neurons and several other brain neurons (Mintz et al., 1992a; Usowicz et al., 1992; cf., Tottene et al., 1996). In both neostriatal and cortical neurons, these currents inactivated very slowly and were activated only by strong depolarization. The inactivation time constant of P-type currents at 0 $\mathrm{mV}$ was on the order of seconds in both cell types. Current activation was well described by a Boltzmann function having a half-activation voltage of $\sim 5 \mathrm{mV}$ in neostriatal medium spiny neurons and $\sim 10 \mathrm{mV}$ in cortical pyramidal neurons (with $5 \mathrm{~mm}$ $\mathrm{Ba}^{2+}$ as the charge carrier).

In contrast, Q-type currents in neostriatal medium spiny and cortical pyramidal neurons typically differed significantly in inactivation kinetics. In cortical neurons, Q-type currents displayed inactivation properties similar to those of $\alpha_{1 \mathrm{~A}}$ currents in oocytes with $50 \%$ or more of the current inactivating during a $400 \mathrm{msec}$ step (Stea et al., 1994). In this regard, cortical Q-type currents were similar to those found previously in other neuron types (Diochot et al., 1995; Randall and Tsien, 1995). On the other hand, Q-type currents in neostriatal medium spiny neurons typically displayed much less inactivation $(\sim 0-15 \%)$ during similar duration steps. In fact, the inactivation kinetics of Q-type currents in neostriatal neurons were similar to those of P-type currents.

Is it possible that P-type currents were misidentified as Q-type in these cells? This seems highly unlikely. In these experiments, cells were exposed to $100 \mathrm{~nm} \mathrm{AgTx}$ for several minutes before exposure to a high concentration $(1 \mu \mathrm{M})$ of AgTx or CTx MVIIC. Because $100 \mathrm{~nm}$ is several orders of magnitude above the estimated $K_{\mathrm{D}}$ of P-type channels for $\operatorname{AgTx}(1-3 \mathrm{~nm})$, this preexposure should have effectively blocked any P-type channels that were present (Mintz et al., 1992a; Randall and Tsien, 1995). This concentration of AgTx will also block some Q-type channels, but this is unimportant to the interpretation of our results. Our goal was simply to unequivocally isolate a group of Q-type channels.

Differences in the steady-state voltage dependence of $\mathrm{P}$ - and Q-type channels in neostriatal medium spiny neurons also argues that Q-type channels were not misidentified by this pharmacological regimen. Although both were high-voltage activated, Q-type channels had significantly less positive half-activation voltages than P-type channels in these cells, having half-activation voltages near $\sim 10 \mathrm{mV}$. This difference is consistent with the differences in inactivation rates based on work in heterologous systems (see below). Taken together, these findings argue that the pharmacological properties of P- and Q-type channels can be dissociated from their biophysical properties. The determinants of the pharmacological properties may reside in other subunits (e.g., $\alpha_{2} \delta$ ) (Walker and De Waard, 1998), splicing (Bourinet et al., 1999), or in post-translational modifications (Gurnett et al., 1996). This proposition is consistent with the heterologous expression literature showing wide variation in the biophysical properties of pharmacologically defined Q-type channels (Sather et al., 1993; Stea et al., 1994; Moreno et al., 1997).

\section{Differences in the properties of Q-type currents are correlated with $\beta$ subunit expression but not $\alpha_{1 \mathrm{~A}}$ splicing}

Although the origin of their pharmacological differences remains to be determined, the single-cell RT-PCR analysis provided some insight into the biophysical heterogeneity of native P- and Q-type channels. Two hypotheses have been advanced to explain the biophysical differences. One proposition is that splice variants of 
A Domain I-II linker sequence

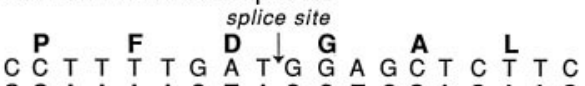
GGA A A A C T A C C T C G A G A A G

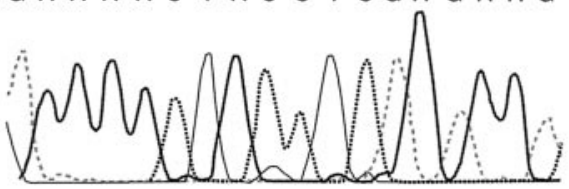

\section{B Dorsal neostriatum mRNA}

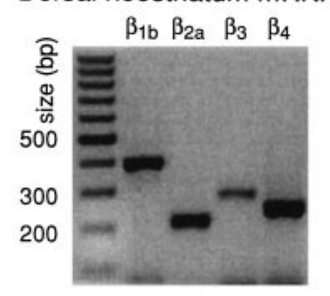

\section{C}

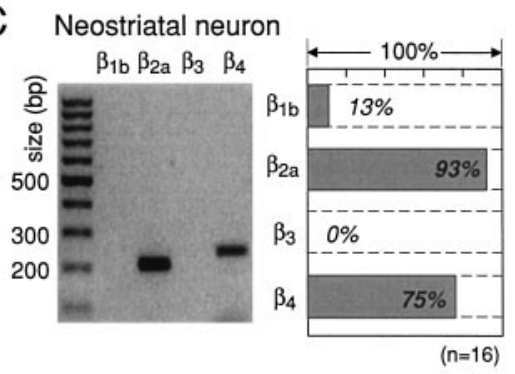

E Neostriatal neurons - serial dilution
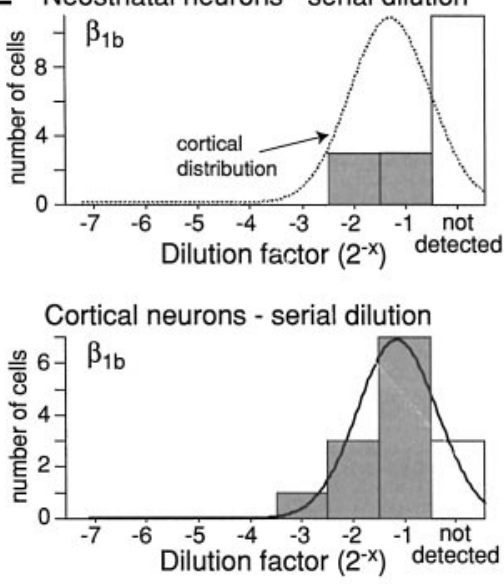

D Cortical neuron
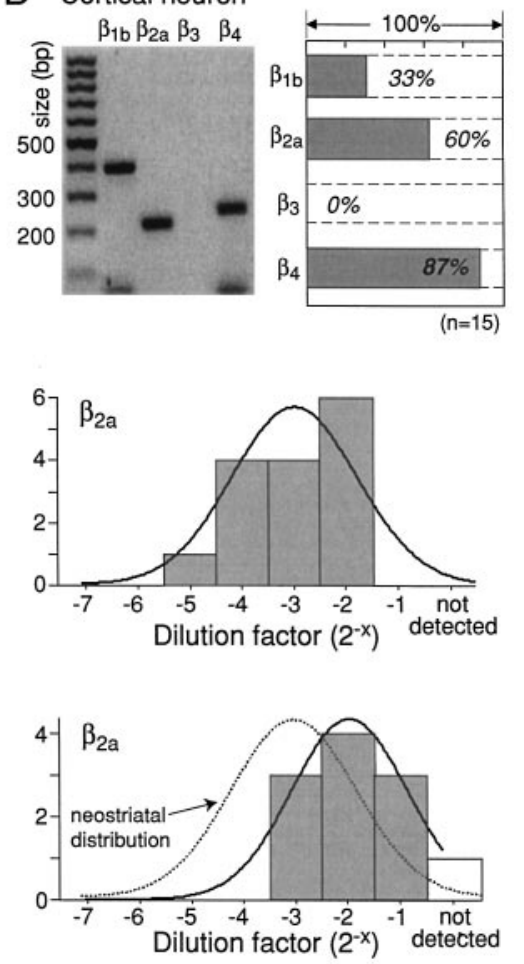

Figure 6. Neostriatal and cortical neurons differ in $\beta$ subunit expression. $A$, Results of dye termination sequencing of the scRT-PCR amplicon encompassing the splice site in the I-II linker region. The amplicon was derived from an individual medium spiny neuron. The signal at each wavelength is represented by a different line type; immediately above the peaks is the base call. Above the cDNA sequence is the predicted mRNA sequence and the corresponding amino acid. The splice site is marked. The sequence corresponds to the $\alpha_{1 \mathrm{Aa}}$ variant. $B$, Gel showing the amplicons produced by RT-PCR analysis of pooled neostriatal mRNA. Note that mRNA for all four $\beta$ subunits was amplified. Similar results were found with cortical mRNA (data not shown). C, The left panel shows a gel in which the amplicons from a single neostriatal neuron have been separated. This particular cell expressed detectable levels of $\beta_{2}$ and $\beta_{4}$ mRNAs. On the right is a summary of data from 16 neurons. $D$, The expression in a single cortical pyramidal neuron. This particular cell expressed detectable levels of $\beta_{1 \mathrm{~b}}, \beta_{2}$, and $\beta_{4}$ mRNAs. On the right is a summary of data from 15 pyramidal neurons. $E$, Summaries of serial dilution experiments designed to generate semiquantitative estimates of mRNA abundance. Note that the abundance of $\beta_{1 \mathrm{~b}}$ was significantly higher $(p<0.05$; Kruskal-Wallis) in cortical pyramidal neurons than medium spiny neurons. Note also that $\beta_{2 \mathrm{a}}$ mRNA was approximately twofold more abundant in medium spiny neurons than cortical neurons ( $p<0.05$; Kruskal-Wallis). $\beta_{4}$ mRNA appeared to be of similar abundance in both cell types $(p>0.05$; Kruskal-Wallis). the $\alpha_{1 \mathrm{~A}}$ subunit give rise to P- and Q-like channels (Bourinet et al., 1999). In Xenopus oocytes, the $\alpha_{1 \mathrm{Aa}}$ splice variant produced channels with fast (Q-like), whereas the $\alpha_{1 \mathrm{Ab}}$ variant produced slower (P-like) inactivation kinetics. However, neostriatal medium spiny neurons (and cortical pyramidal neurons) exclusively expressed the "a" and not the "b" or "c" splice variant $\left(\alpha_{1 \mathrm{Aa}}\right)$. So, although this may account for differences in other cell types, it cannot account for the slow inactivation kinetics of Q-type currents in neostriatal neurons.

An alternative hypothesis is that the differences in inactivation kinetics are attributable to $\beta$ subunits. Several studies (Stea et al., 1994; De Waard and Campbell, 1995) have suggested that $\beta_{2 \mathrm{a}^{-}}$ containing $\alpha_{1 \mathrm{~A}}$ channels are slowly inactivating (P-like), whereas $\beta_{1 \mathrm{~b}^{-}}, \beta_{3^{-}}$, and $\beta_{4}$-containing channels are more rapidly inactivating (Q-like) (cf., Moreno et al., 1997). Our results are largely in agreement with this explanation. As predicted, $\beta_{2 a}$ mRNA was found in both neostriatal and cortical pyramidal neurons expressing slowly inactivating P-type currents. Furthermore, in neostriatal medium spiny neurons, in which $\beta_{2 a}$ mRNA was approximately twofold more abundant than in cortical pyramidal neurons, Q-type currents also were slowly inactivating with time constants similar to those seen in heterologous systems. In cortical pyramidal neurons, in which Q-type currents inactivated more rapidly, $\beta_{1 \mathrm{~b}}$ mRNA was present at considerably higher levels (more than twofold) than in neostriatal medium spiny neurons. An additional observation in support of this proposition is that cortical Q-type channels activated at more negative membrane potentials than Q-type channels in neostriatal medium spiny neurons. Studies in heterologous systems have found that $\alpha_{1 \mathrm{~A}}$ channels having $\beta_{1 \mathrm{~b}}$ (or $\beta_{4}$ ) subunits activated at more negative potentials than $\beta_{2 \mathrm{a}}$-containing channels (Castellano et al., 1993b).

A seeming complication in this interpretation is the detection of $\beta_{4}$ subunit mRNA at roughly equal levels in both neostriatal medium spiny neurons and cortical pyramidal neurons. In principle, the coexpression of $\beta$ subunits in individual cells should result in competitive binding of $\alpha_{1 \mathrm{~A}}$ subunits. Often, the inactivation of Q-type currents in cortical pyramidal neurons had fast and slow components, suggesting channel heterogeneity. Analysis of $\beta$ subunit interactions with $\alpha_{1 \mathrm{~A}}$ subunits suggests that although all four $\beta$ subunits are capable of binding to the principal interaction domain in the $\alpha_{1 \mathrm{~A}}$ I-II linker, $\beta_{4}$ and $\beta_{2 \mathrm{a}}$ subunits have a higher affinity for this site than $\beta_{1 \mathrm{~b}}$ or $\beta_{3}$ subunits (Liu et al., 1996). A similar affinity difference has been found in a C-terminal interaction domain of the $\alpha_{1 \mathrm{~A}}$ subunit (Walker et al., 1998). However, because our scRT-PCR analysis does not allow us gauge absolute mRNA levels, little can be concluded from our results about the abundance of $\beta_{4}$ mRNA relative to that of $\beta_{2 \mathrm{a}}$ or $\beta_{1 \mathrm{~b}}$ subunit mRNAs in single cells. Differences in RT or PCR 
efficiency of the $\beta$ templates can have dramatic effects on estimates of abundance (Zamorano et al., 1996). Quantitative studies at the single-cell level employing cRNA standards will be required to provide an answer to this question. Nevertheless, our results argue that the ratio of $\beta_{2 \mathrm{a}} / \beta_{4}$ mRNA ratio is higher in neostriatal medium spiny neurons that in cortical pyramidal neurons, favoring the hypothesis that $\beta_{2 \mathrm{a}}$ association with $\alpha_{1 \mathrm{~A}}$ subunits is responsible for the slow inactivation kinetics of Q-type currents.

It should also be noted that it is highly likely that other factors impact channel assembly and subunit composition. For example, $\alpha_{1}$ and $\beta$ subunit isoforms may be localized to particular subcellular compartments, restricting potential interactions. In cerebellar Purkinje neurons $\beta_{2 \mathrm{a}}$ (and $\beta_{1 \mathrm{~b}}$ ) protein is found primarily in the soma, whereas $\beta_{3}$ protein is found primarily in the dendrites (Volsen et al., 1997). This difference may be a consequence in part of $\beta_{2 \mathrm{a}}$ subunit palmitoylation (Chien et al., 1995; Qin et al., 1998). Evidence for $\beta$ subunit chaperoning of $\alpha_{1}$ subunits to the cell surface (Berrow et al., 1995; Brice et al., 1997) also suggests that assembly decisions may be regulated by targeted interactions, rather than simply mass action. Both neostriatal and cortical neurons also express class $\mathrm{B}, \mathrm{C}, \mathrm{D}$, and $\mathrm{E} \alpha_{1}$ subunit mRNA and their corresponding channels (Bargas et al., 1994; Lorenzon and Foehring, 1995; Mermelstein and Surmeier, 1997; our unpublished observations), providing a variety of partners for $\beta$ subunit assembly. In neostriatal medium spiny neurons, both $\mathrm{N}$ - and R-type $\mathrm{Ca}^{2+}$ currents display pronounced voltage-dependent inactivation (our unpublished observations), suggesting that $\alpha_{1 \mathrm{~B}}$ and $\alpha_{1 \mathrm{E}}$ subunits may preferentially assemble with $\beta_{4}$ subunits. Because these channels types constitute a large fraction of all the $\mathrm{Ca}^{2+}$ channels in the somatodendritic membrane of neostriatal neurons, they may restrict the assembly of $\beta_{4}$ subunits with $\alpha_{1 \mathrm{~A}}$ subunits simply by reducing $\beta_{4}$ availability.

\section{Functional implications}

What are the potential functional consequences of variation in $\beta$ subunit expression and Q-type channel biophysics? Biochemical and physiological studies of Q-type channels has revealed their involvement in a variety of cellular functions, many of which would be affected by alterations in inactivation rates and voltage dependence. For example, Q-type channels have been implicated in transmitter release (Lovinger et al., 1994; Wheeler et al., 1994; $\mathrm{Wu}$ and Saggau, 1995). Acceleration of inactivation rates should result in decreased terminal $\mathrm{Ca}^{2+}$ entry in response to repetitive terminal spiking. Conversely, the elimination of inactivation should make Q-type channels relatively frequency-insensitive. Although a clear functional role for dendritic Q-type channels has not been established, they should contribute to active processes regulating synaptic integration (Magee et al., 1998). They have also been implicated in the regulation of slow afterhyperpolarizations and spike frequency adaptation in cortical pyramidal neurons (Pineda and Foehring, 1998). This contribution could be minimized or eliminated by maintained synaptic depolarization or dendritic spiking in cortical pyramidal neurons but not in neostriatal medium spiny neurons.

\section{REFERENCES}

Bargas J, Howe A, Eberwine J, Cao Y, Surmeier DJ (1994) Cellular and molecular characterization of $\mathrm{Ca} 2+$ currents in acutely-isolated, adult rat neostriatal neurons. J Neurosci 14:6667-6686.

Berrow NS, Campbell V, Fitzgerald EM, Brickley K, Dolphin AC (1995) Antisense depletion of $\beta$-subunits modulates the biophysical and pharmacological properties of neuronal calcium channels. J Physiol (Lond) 482:481-491.
Bito H, Deisseroth K, Tsien RW (1997) Ca2+-dependent regulation in neuronal gene expression. Curr Opin Neurobiol 7:419-429.

Bourinet E, Soong TW, Sutton K, Slaymaker S, Mathews E, Monteil A, Zamponi GW, Nargeot J, Snutch TP (1999) Splicing of $\alpha_{1 \mathrm{~A}}$ subunit gene generated phenotypic variants of P-and Q-type calcium channels. Nat Neurosci 2:407-415.

Brice NL, Berrow NS, Campbell V, Page KM, Brickley K, Tedder I, Dolphin AC (1997) Importance of the different $\beta$ subunits in the membrane expression of the $\alpha 1 \mathrm{~A}$ and $\alpha 2$ calcium channel subunits: studies using a depolarization-sensitive $\alpha 1 \mathrm{~A}$ antibody. Eur J Neurosci 9:749-759.

Castellano A, Wei X, Birnbaumer L, Perez-Reyes E (1993a) Cloning and expression of a third calcium channel $\beta$ subunit. J Biol Chem 268:3450-3455.

Castellano A, Wei X, Birnbaumer L, Perez-Reyes E (1993b) Cloning and expression of a neuronal calcium channel $\beta$ subunit. J Biol Chem 268:12359-12366.

Chien AJ, Zhao X, Shirokov RE, Puri TS, Chang CF, Sun D, Rios E, Hosey MM (1995) Roles of a membrane-localized $\beta$ subunit in the formation and targeting of functional L-type $\mathrm{Ca} 2+$ channels. J Biol Chem 270:30036-30044.

De Waard M, Campbell KP (1995) Subunit regulation of the neuronal $\alpha$ $1 \mathrm{~A} \mathrm{Ca} 2+$ channel expressed in Xenopus oocytes. J Physiol (Lond) 485:619-634.

De Waard M, Gurnett CA, Campbell KP (1996) Structural and functional diversity of voltage-activated calcium channels. Ion Channels 4:41-87.

Desmadryl G, Chambard JM, Valmier J, Sans A (1997) Multiple voltage-dependent calcium currents in acutely isolated mouse vestibular neurons. Neuroscience 78:511-522.

Diochot S, Richard S, Valmier J (1995) Diversity of voltage-gated calcium currents in large diameter embryonic mouse sensory neurons. Neuroscience 69:627-641.

Eliot LS, Johnston D (1994) Multiple components of calcium current in acutely dissociated dentate gyrus granule neurons. J Neurophysiol 72:762-777.

Foehring RC, Armstrong WE (1996) Pharmacological dissection of high-voltage-activated $\mathrm{Ca} 2+$ current types in acutely dissociated rat supraoptic magnocellular neurons. J Neurophysiol 76:977-983.

Gerfen C (1992) The neostriatal mosaic: multiple levels of compartmental organization in the basal ganglia. Annu Rev Neurosci 15:285-320.

Gillard SE, Volsen SG, Smith W, Beattie RE, Bleakman D, Lodge D (1997) Identification of pore-forming subunit of P-type calcium channels: an antisense study on rat cerebellar Purkinje cells in culture. Neuropharmacology 36:405-409.

Gurnett CA, De Waard M, Campbell KP (1996) Dual function of the voltage-dependent $\mathrm{Ca} 2+$ channel $\alpha 2 \delta$ subunit in current stimulation and subunit interaction. Neuron 16:431-440.

Hamill OP, Marty A, Neher E, Sakmann B, Sigworth FJ (1981) Improved patch-clamp techniques for high resolution current recording from cells and cell-free membrane patches. Pflügers Arch 391:85-100.

Hernandez-Lopez S, Bargas J, Surmeier DJ, Reyes A, Galarraga E (1997) D1 receptor activation enhances evoked discharge in neostriatal medium spiny neurons by modulating an L-type Ca2+ conductance. J Neurosci 17:3334-3342.

Hille B (1992) Ionic channels of excitable membranes. Sunderland, MA: Sinauer.

Hillyard DR, Monje VD, Mintz IM, Bean BP, Nadasdi L, Ramachandran J, Miljanich G, Azimi-Zoonooz A, McIntosh JM, Cruz LJ, Imperial JS, Olivera BM (1992) A new Conus peptide ligand for mammalian presynaptic Ca2 + channels. Neuron 9:69-77.

Holliday J, Adams RJ, Sejnowski TJ, Spitzer NC (1991) Calciuminduced release of calcium regulates differentiation of cultured spinal neurons. Neuron 7:787-796.

Lancaster B, Nicoll RA, Perkel DJ (1991) Calcium activates two types of potassium channels in rat hippocampal neurons in culture. J Neurosci 11:23-30.

Letts VA, Felix R, Biddlecome GH, Arikkath J, Mahaffey CL, Valenzuela A, Bartlett FS, 2nd, Mori Y, Campbell KP, Frankel WN (1998) The mouse stargazer gene encodes a neuronal $\mathrm{Ca} 2+$-channel gamma subunit. Nat Genet 19:340-347.

Liu H, De Waard M, Scott VES, Gurnett CA, Lennon VA, Campbell KP (1996) Identification of three subunits of the high affinity $\omega$-conotoxin MVIIC-sensitive Ca2+ channel. J Biol Chem 271:13804-13810.

Llano I, Leresche N, Marty A (1991) Calcium entry increases the sensitivity of cerebellar Purkinje cells to applied GABA and decreases inhibitory synaptic currents. Neuron 6:565-574. 
Llinas R, Sugimori M, Lin JW, Cherksey B (1989) Blocking and isolation of a calcium channel from neurons in mammals and cephalopods utilizing a toxin fraction (FTX) from funnel-web spider poison. Proc Natl Acad Sci USA 86:1689-1693.

Llinas R, Sugimori M, Hillman DE, Cherksey B (1992) Distribution and functional significance of the P-type, voltage-dependent $\mathrm{Ca} 2+$ channels in the mammalian central nervous system. Trends Neurosci 15:351-355.

Lorenzon NM, Foehring RC (1995) Characterization of pharmacologically identified voltage-gated calcium channel currents in acutely isolated rat neocortical neurons. I. Adult neurons. J Neurophysiol 73:1430-1442.

Lovinger DM, Merritt A, Reyes D (1994) Involvement of N- and non$\mathrm{N}$-type calcium channels in synaptic transmission at corticostriatal synapses. Neuroscience 62:31-40.

Magee J, Hoffman D, Colbert C, Johnston D (1998) Electrical and calcium signaling in dendrites of hippocampal pyramidal neurons. Annu Rev Physiol 60:327-346.

McDonough SI, Swartz KJ, Mintz IM, Boland LM, Bean BP (1996) Inhibition of calcium channels in rat central and peripheral neurons by $\omega$-conotoxin MVIIC. J Neurosci 16:2612-2623.

Mermelstein PG, Surmeier DJ (1997) A calcium channel reversibly blocked by $\omega$-conotoxin GVIA lacking the class $\mathrm{D} \alpha 1$ subunit. NeuroReport 8:485-489.

Mintz IM, Adams ME, Bean BP (1992a) P-type calcium channels in rat central and peripheral neurons. Neuron 9:85-95.

Mintz IM, Venema VJ, Swiderek KM, Lee TD, Bean BP, Adams ME (1992b) P-type calcium channels blocked by the spider toxin $\omega$-AgaIVA. Nature 355:827-829.

Mintz IM, Sabatini BL, Regehr WG (1995) Calcium control of transmitter release at a cerebellar synapse. Neuron 15:675-688.

Moreno H, Rudy B, Llinas R (1997) $\beta$ subunits influence the biophysical and pharmacological differences between P- and Q-type calcium currents expressed in a mammalian cell line. Proc Natl Acad Sci USA 94:14042-14047.

Mori Y, Friedrich T, Kim M, Mikami A, Nakai J, Ruth P, Bosse E, Hofmann F, Flockerzi V, Furuichi T, Mikowshiba K, Imoto K, Tanabe T, Numa S (1991) Primary structure and functional expression from complementary DNA of a brain calcium channel. Nature 350:398-402.

Niidome T, Teramoto T, Murata Y, Tanaka I, Seto T, Sawada K, Mori Y, Katayama K (1994) Stable expression of the neuronal BI (class A) calcium channel in baby hamster kidney cells. Biochem Biophys Res Commun 203:1821-1827.

Perez-Reyes E, Castellano A, Kim HS, Bertrand P, Baggstrom E, Lacerda AE, Wei XY, Birnbaumer L (1992) Cloning and expression of a cardiac/brain $\beta$ subunit of the L-type calcium channel. J Biol Chem 267:1792-1797.

Piedras-Renteria ES, Tsien RS (1998) Antisense oligonucleotides against $\alpha 1 \mathrm{E}$ reduces $\mathrm{R}$-type calcium currents in cerebellar granule cells. Proc Natl Acad Sci USA 95:7760-7765.

Pineda JC, Waters RS, Foehring RC (1998) Specificity in the interaction of HVA $\mathrm{Ca}^{2+}$ channel types with $\mathrm{Ca}^{2+}$-dependent AHPs and firing behavior in neocortical pyramidal neurons. J Neurophysiol 79:2522-2534.

Pinto A, Gillard S, Moss F, Whyte K, Brust P, Williams M, Stauderman K, Harpold M, Lang B, Newsom-Davis J, Bleakman D, Lodge D, Boot J (1998) Human autoantibodies specific for the 1A calcium channel subunit reduce both P-type and Q-type calcium currents in cerebellar neurons. Proc Natl Acad Sci USA 8328-8333.

Pragnell M, De Waard M, Mori Y, Tanabe T, Snutch TP, Campbell KP (1994) Calcium channel $\beta$-subunit binds to a conserved motif in the I-II cytoplasmic linker of the $\alpha$ 1-subunit. Nature 368:67-70.

Pragnell M, Sakamoto J, Jay SD, Campbell KP (1991) Cloning and tissue-specific expression of the brain calcium channel $\beta$-subunit. FEBS Lett 291:253-258.

Qin N, Platano D, Olcese R, Costantin JL, Stefani E, Birnbaumer L (1998) Unique regulatory properties of the type $2 \mathrm{a} \mathrm{Ca} 2+$ channel $\beta$ subunit caused by palmitoylation. Proc Natl Acad Sci USA 95:4690-4695.

Randall A, Tsien RW (1995) Pharmacological dissection of multiple types of $\mathrm{Ca} 2+$ channel currents in rat cerebellar granule neurons. J Neurosci 15:2995-3012.

Sakurai T, Hell JW, Woppmann A, Miljanich GP, Catterall WA (1995) Immunochemical identification and differential phosphorylation of alternatively spliced forms of the $\alpha$ A subunit of brain calcium channels. J Biol Chem 270:21234-21242.
Sakurai T, Westenbroek RE, Rettig J, Hell J, Catterall WA (1996) Biochemical properties and subcellular distribution of the BI and rbA isoforms of $\alpha$ 1A subunits of brain calcium channels. J Cell Biol 134:511-528.

Sather WA, Tanabe T, Zhang JF, Mori Y, Adams ME, Tsien RW (1993) Distinctive biophysical and pharmacological properties of class A (BI) calcium channel $\alpha 1$ subunits. Neuron 11:291-303.

Snutch TP, Reiner PB (1992) Ca2+ channels: diversity of form and function. Curr Opin Neurobiol 2:247-253.

Song W-J, Tkatch T, Baranauskas G, Kitai ST, Ichinohe N, Surmeier DJ (1998) Somatodendritic depolarization-activated potassium currents in rat neostriatal cholinergic interneurons are predominantly of the A-type and attributable to co-expression of Kv4.2 and Kv4.1 subunits. J Neurosci 18:3124-3137.

Starr TV, Prystay W, Snutch TP (1991) Primary structure of a calcium channel that is highly expressed in the rat cerebellum. Proc Natl Acad Sci USA 88:5621-5625.

Stea A, Tomlinson WJ, Soong TW, Bourinet E, Dubel SJ, Vincent SR, Snutch TP (1994) Localization and functional properties of a rat brain $\alpha$ 1A calcium channel reflect similarities to neuronal Q- and P-type channels. Proc Natl Acad Sci USA 91:10576-10580.

Surmeier DJ, Song WJ, Yan Z (1996) Coordinated expression of dopamine receptors in neostriatal medium spiny neurons. J Neurosci 16:6579-6591.

Tanaka O, Sakagami H, Kondo H (1995) Localization of mRNAs of voltage-dependent $\mathrm{Ca}(2+)$-channels: four subtypes of $\alpha 1$ - and $\beta$-subunits in developing and mature rat brain. Brain Res Mol Brain Res 30:1-16.

Tkatch T, Baranauskas G, Surmeier DJ (1998) Basal forebrain neurons adjacent to the globus pallidus co-express GABAergic and cholinergic marker mRNAs. NeuroReport 9:1935-1939.

Tottene A, Moretti A, Pietrobon D (1996) Functional diversity of P-type and R-type calcium channels in rat cerebellar neurons. J Neurosci 16:6353-6363.

Tsien RW, Lipscombe D, Madison DV, Bley KR, Fox AP (1995) Reflections on $\mathrm{Ca}(2+)$-channel diversity, 1988-1994. Trends Neurosci 18:52-54.

Usowicz MM, Sugimori M, Cherskey B, Llinas R (1992) P-type calcium channels in the somata and dendrites of adult cerebellar Purkinje cells. Neuron 9:1185-1199.

Volsen SG, Day NC, McCormack AL, Smith W, Craig PJ, Beattie RE, Smith D, Ince PG, Shaw PJ, Ellis SB, Mayne N, Burnett JP, Gillespie A, Harpold MM (1997) The expression of voltage-dependent calcium channel $\beta$ subunits in human cerebellum. Neuroscience 80:161-174.

Walker D, De Waard M (1998) Subunit interaction sites in voltagedependent $\mathrm{Ca} 2+$ channels: role in channel function. Trends Neurosci 21:148-154.

Walker D, Bichet D, Campbell KP, De Waard M (1998) A $\beta 4$ isoformspecific interaction site in the carboxyl-terminal region of the voltagedependent $\mathrm{Ca} 2+$ channel $\alpha 1$ A subunit. J Biol Chem 273:2361-2367.

Wang G, Dayanithi G, Kim S, Hom D, Nadasdi L, Kristipati R, Ramachandran J, Stuenkel EL, Nordmann JJ, Newcomb R, Lemos JR (1997) Role of Q-type Ca2+ channels in vasopressin secretion from neurohypophysial terminals of the rat. J Physiol (Lond) 502:351-363.

Westenbroek RE, Sakurai T, Elliott EM, Hell JW, Starr TV, Snutch TP, Catterall WA (1995) Immunochemical identification and subcellular distribution of the $\alpha 1 \mathrm{~A}$ subunits of brain calcium channels. J Neurosci 15:6403-6418.

Wheeler DB, Randall A, Tsien RW (1994) Roles of N-type and Q-type $\mathrm{Ca} 2+$ channels in supporting hippocampal synaptic transmission. Science 264:107-111.

Wu LG, Saggau P (1995) Block of multiple presynaptic calcium channel types by $\omega$-conotoxin- MVIIC at hippocampal CA3 to CA1 synapses. J Neurophysiol 73:1965-1972.

Yan Z, Song WJ, Surmeier J (1997) D2 dopamine receptors reduce $\mathrm{N}$-type $\mathrm{Ca} 2+$ currents in rat neostriatal cholinergic interneurons through a membrane-delimited, protein-kinase-C-insensitive pathway. J Neurophysiol 77:1003-1015.

Zamorano PL, Mahesh VB, Brann DW (1996) Quantitative RT-PCR for neuroendocrine studies. A minireview. Neuroendocrinology 63:397-407.

Zhang JF, Randall AD, Ellinor PT, Horne WA, Sather WA, Tanabe T, Schwarz TL, Tsien RW (1993) Distinctive pharmacology and kinetics of cloned neuronal $\mathrm{Ca} 2+$ channels and their possible counterparts in mammalian CNS neurons. Neuropharmacology 32:1075-1088. 